\title{
Business Education, Self-Fulfilling Prophecy, and the Inherent Responsibility of Scholars
}

\author{
Michael GONIN \\ HEC, University of Lausanne \\ $\mathrm{CH}-1015$ Lausanne-Dorigny \\ michael.gonin@unil.ch \\ ++41216923381
}

This is the version before the final editing of the article:

Gonin, M. 2007. Business research, self-fulfilling prophecy, and the inherent responsibility of scholars. Journal of Academic Ethics, 5(1): 33-58.

DOI: http://dx.doi.org/10.1007/s10805-007-9039-3

The original publication is available at www.springerlink.com :

http://www.springerlink.com/content/81314315p8558k52/ 


\section{ABSTRACT}

Business research and teaching institutions play an important role in shaping the way businesses perceived their relations to the broader society and its moral expectations. Hence, as ethical scandals recently arose in the business world, questions related to the civic responsibilities of business scholars and of the role business schools play in society have gained wider interest.

In this article, I argue that these ethical shortcomings are at least partly resulting from the mainstream business model with its taken-for granted basic assumptions such as the homo economicus concept or the value-neutrality of business research. As a result a redefinition of the role and civic responsibilities of business scholars for business practice imply a thorough analysis of these assumptions if not their redefinition. The taken-for-grantedness of the mainstream business model is questioned by the transformation of the societal context in which business activities are embedded. Its value-neutrality in turn is challenged by self-fulfilling prophecy effects, which highlight the normative influence of business schools.

In order to critically discuss some basic assumptions of mainstream business theory, I propose to draw parallels with the corporate citizenship concept and the stakeholder theory, as their integrated approach of the relation between business practice and the broader society provides interesting insights for the re-embedding of business science. Finally, I will discuss the implications of these new assumptions for business education.

Keywords: academic citizenship; business ethics; business schools; corporate citizenship; philosophy of science; science-society interface; self-fulfilling prophecy; social responsibility; stakeholder theory. 


\section{Business Education, Self-Fulfilling Prophecy, and the Inherent Responsibility of Scholars}

\section{INTRODUCTION}

Business research and teaching institutions play an important role in shaping the way businesses perceive their relations to the broader society and its moral expectations. In the same way, they shape the perceptions managers have of their individual roles and their responsibilities toward society (Ghoshal \& Moran, 1996; Mintzberg, 2004). In consequence, business scholars do not act in a social vacuum; rather, the practical impact of their research strongly embeds business scientists in the practical life of the broader society (Merton, 1973 [1938], p. 263). Hence, as ethical scandals recently arose in the business world (see e.g., Unerman \& O'Dwyer, 2004), some authors related these ethical shortcomings to mainstream business education (Cagle \& Baucus, 2006; Koehn, 2005; Lopez, Rechner \& Olson-Buchanan, 2005; Michael, 2006). Different studies point toward a link between business or economics education and cheating (McCabe, Butterfield \& Trevino, 2006) or illegal activities in corporations (Williams, Barrett \& Brabston, 2000). Ghoshal even affirms that "business schools have actively freed their students from any sense of moral responsibility" (Ghoshal, 2005, p. 76). In consequence, the questions related to the civic responsibilities of business scholars toward students and of the role business schools (ought to) play in society have gained wider interest (e.g., Boyce, 2006; Karri, Caldwell, Antonacopoulou \& Neagle, 2005; Koehn, 2005; Mitroff, 2004).

In this article, I propose to answer the questions related to the role and responsibilities of business scholars for today's and tomorrow's business practices by looking at the factors which led the actual 
mainstream business model to have negative consequences for business practice. Following Argyris double-look learning model (1976), I assume that searching for the roots of the problem will provide better solutions than focusing on short-term patches. Examining the relation between the actual mainstream business paradigm and the failure of some managers to honor their moral obligations should therefore provide important insights for the discussion about the business schools' role in shaping business practice. These insights will help identify the possible contributions of business schools to a better alignment of business practices with the expectations of the broader society. Further, examining the influence of mainstream business theory on individual behavior and on societal structures might help defining the civic responsibility that business scholars bear for the practical consequences of their theoretical models and their teaching .

In the first part of the article, I will argue that the ethical problems encountered in today's business practice are due to the basic assumptions on which mainstream business theory and education is built scientific methodology, value-neutrality, and specialization. These assumptions, developed in a specific context, certainly contributed to the rise of the Western liberal market economy and its relative high level of welfare. However, as the societal context evolved and as the self-fulfilling prophecy effect gave the business model a strong normative authority, these assumptions became the cause of a strong disembedding of the business world from the broader society, and of the managers' tendency to neglect ethical reflections in their work (Bird \& Waters, 1989; Rainelli-Le Montagner, 2006). Furthermore, these assumptions tended to protect scholars from the duty to reflect upon the societal consequences of their research and the respective ethical responsibility they might have (with a few exceptions such as Granovetter, 1985; Polanyi, 1957 [1944]; and more recently Ferraro, Pfeffer \& Sutton, 2005; Ghoshal, 2005).

In consequence, the answer to the question of 'how business schools and business scholars could help managers better integrate their civic obligations into their work' lies in a thorough analysis and redefinition of these assumptions. In the second part of the article, I will therefore propose to replace 
the actual disembedded business model by a model which takes into account the embeddedness of business scholars in the broader society, and the inherent civic responsibilities. In order to discuss this new relation between business science and society, I will draw parallels with two approaches of the business-society relation: The corporate citizenship concept and the stakeholder theory indeed were developed in the past decades in order to counter the disembedding of business practice from the broader society. As such, they can provide interesting insights for the re-embedding of business science into the broader society. The corporate citizenship approach, conceiving firms as 'citizens' bearing right and duties toward society, can help define the specific place of scientists in the broader society. Further, Freeman's stakeholder theory (1983) allows a systematic analyze of the numerous groups influenced by the scholars' research and teaching.

\section{THE ASSUMPTIONS OF THE MAINSTREAM BUSINESS PARADIGM}

Today's mainstream business theory conceives the business system - defined here as the network of economics actors and the relationships between them - as an autonomous system specialized in the production of good and services (e.g., Crook, 2005; Levitt, 1958; Luhmann, 1984; see critically Dubbink, 2004; Habermas, 1996, pp. 78-79; Ulrich, 2006). This system is supposed to be most efficient if it follows its own rules which deal with all aspects of the business life. These rules are derived from a specific understanding of the economic actor and of the market. Economic actors are conceived as perfectly rational, egocentric, profit maximizing Homines Economici (HE) (Friedman, 1970; Jensen \& Meckling, 1976; Williamson, 1975), and market is expected to implicitly transform the self-interested transactions into general welfare (Levitt, 1958; Stigler, 1950a, 1950b; see critically Peter, 2004). Ethics represents therefore merely a means to reach economic ends (see e.g., McWilliams, Siegel \& Wright, 2006) -, or is at best synonymous with philanthropy unrelated to the core business activities (Porter \& Kramer, 2002; see critically Scherer \& Palazzo, 2007, forthcoming). 
This approach of business represents the mainstream business paradigm (MBP) (Vranceanu, 2005, p. 94; see also Merton, 1968); as paradigm, MBP provides a set of assumptions and methodologies which influence both the definition of research questions and the interpretation of observed phenomena (Kuhn, 1972, pp. 32-33, 54-55). This delineation of research questions and methodology shapes most research in business, and consequently the knowledge developed in that field (Blaug, 2001; Chalmers, 1987; Feyerabend, 1987; Kuhn, 1972; Lakatos, 1978, p. 49). Furthermore, education also relies on this paradigm, and strengthens its dominating position as it transmits the paradigm's hypotheses to the next generation (Kuhn, 1970, pp. 237-238; see also Carrithers \& Peterson, 2006; M. Weber, 1959 [1917]). Trevino and Weaver assert that "academics spend years in Ph.D. programs being shaped and socialized to a dominant paradigm that leads them to make assumptions, to ask certain types of questions, and to search for answers using accepted methodologies" (Trevino \& Weaver, 1994, pp. 115-116; see also Mintzberg, 2004).

In this section, I will discuss three basic assumptions of the mainstream business paradigm and their influence on the interactions of business theory and practice with the broader society. I will then show how changes in the societal context and self-fulfilling prophecy effects challenge these assumptions, questioning the role and responsibilities of business scholars.

Assumption 1 - Science Has Specific Aims and Rules: Science is conceived as a specific system dedicated to enhancing knowledge about facts and relations between them. To reach this goal, it relies on specific rules (see e.g., Merton, 1973 [1942]; Popper, 1978). The universalism rule requires that the validity criteria of truth depend on impersonal, universally recognized methodologies. Communalism refers to the free access to scientific results so that any scientist can see, analyze, verify, and challenge them. The ideal of disinterestedness supposes that researchers should work not for their own sake or fame, but out of a desire to advance science. Finally, organized skepticism demands scientists to be skeptical and only trust - in their scientific work - facts that has been empirically verified. Models that encounters empirical falsifications are to be corrected or abandoned (Popper, 1973). 
Assumption 2 - Science is Value-Neutral: The second assumptions stipulates that science is value-free. In a time where all political parties were trying to find 'scientific' justification for their ideologies and professors tended to include their personal ideological or political opinions in their teaching, scientists asked for clearly delineating the fields of research and teaching from covert value-laden propaganda (M. Weber, 1959 [1917], 1965 [1917]; Merton, 1973 [1938], p. 260; Popper, 2003 [1943], p. xviii). Scientists are to reserve their personal opinions for public platforms and present mere facts in their lectures.

Assumption 3 - Specialization Is Efficient: The autonomy of science and its specific rules rely on the idea that specialization allows a systematic and efficient approach of the complex world, as each task or problem is efficiently managed by 'experts' (see Beck, 1992; Giddens, 1991, p. 18; Jonas, 1984). Further, specialization ensures that scientific knowledge is not biased by some external political or ideological influence, and that professors teach specific facts rather than promoting their personal opinions (M. Weber, 1959 [1917], 1965 [1917]).

\section{THE LIMITED VALIDITY OF THESE ASSUMPTIONS IN MBP}

MBP strongly relies on these three assumptions. A precise methodology guides theory building and empirical research in business science (Bacharach, 1989; Dubin, 1976), and a positivist approach based on empirically verifiable theories aims at ensuring a high objectivity and reliability for its theories (see e.g., L. Donaldson, 2005; see critically Pfeffer \& Fong, 2002). Further, MBP focuses on factual knowledge. Many business scholars develop and test models explaining how a given goal can be reached more efficiently, but do not discuss whether the proposed means correspond to the ethical expectations of the broader society (see articles such as Bonardi \& Keim, 2005; Oliver, 1991; see critically Béchard \& Grégoire, 2005; Blommestein, 2006). Finally, the specialization assumption justifies MBP's reduction of individuals to the role of economic agents separated from other societal roles (Rees, 1985a, 1985b): Economic actors are supposed to follow only HE values, and ignore other 
objectives or values (Friedman, 1970; Jensen, 2002; see critically Dubbink, 2004). MBP does not deny the importance non-economic responsibilities, but assumes that these responsibilities are to be dealt with outside the business system (Luhmann, 1982, 1984).

These three assumptions and their influence on MBP certainly contributed to the rise of the Western liberal market economy with its relative high level of welfare. However, they were developed in a specific societal context. As the context evolves, and self-fulfilling prophecy effects grant MBP with normative authority, these assumptions might loose their relevance. Moreover, these assumptions might prevent a thorough discussion of MBP's increasing normative influence; this discussion however might represent an unavoidable step in the redefinition of business scholars' responsibilities for the social or ethical consequences of their research and teaching.

This section will discuss therefore the downsides of these assumptions, and present how they prevented a better alignment of business theory and practice with the expectations of the broader society. I will argue that holding tight to these assumptions in today's context might show some paradoxes. The second part of the article will then present alternative assumptions which would take into account these critics and encourage a re-embedding of business theory and practice into the broader society.

\section{LIMITATIONS OF THE SCIENTIFIC RULES IN MBP}

As the first assumption - specific scientific rules - contributed to the development of reliable knowledge and models in business, some authors began to hope that MBP will eventually form a "systematized structure capable of both explaining and predicting phenomena" (Seth \& Zinkhan, 1991, p. 75). This hope bears however the risk to forget that scientific contributions are limited to the understanding of general principles and cannot lead to laws for all situations (Hayek, 1937; Hayek, 1949 [1945], p. 7; Hayek, 1984 [1973]; Popper, 1978, 2003 [1943]; M. Weber, 1992 [1904]). Furthermore, 'organized skepticism' is to be questioned as many of MBP's theories show important flaws (Herrnstein, 1993; Seth \& Zinkhan, 1991; see also the falsification assumption in Popper, 1973). 
At the level of individual actors, the HE concept is under harsh criticisms (Mintzberg, Simons \& Basu, 2002; Rocha \& Ghoshal, 2006). Rational behavior is questioned by studies of Tversky and Kahneman (showing the limited amount of information taken into account in decision processes, 1981; 1986) or Lye (decision process as decision waves, 2005). Fehr and Gächter show that people are ready to act in an socially responsible manner and punish behaviors that are socially not correct, even if it is not profitable for themselves (2002; see also Buchholz \& Rosenthal, 2005; Steenhaut \& van Kenhove, 2006). More generally, individual actors within the business system seem to suffer from the narrow definition of economic rationality and its conflict with their personal values, and strive for a holistic approach of life and work (Benefiel, 2005; Conlin, 1999; Englis \& Solomon, 1997; Hira \& Ferrie, 2006; Kozinets \& Handelman, 2004; Nisan, 1993; S. Sen, Gürhan-Canli \& Morwitz, 2001; Wall, 2003).

At the level of the organization, a mere economic approach of the firm often falls short. The concept of common purpose seems to better explain intra-organizational coordination than MBP's transaction cost theory (Ghoshal \& Moran, 1996, p. 37), and studies show that values also play a role in the relation between employees and corporations (Rousseau \& Tijoriwala, 1998; Thompson \& Bunderson, 2003). Leadership theory seizes the importance of communicating a broader concept of meaning and a vision for employees in order for them to better adhere to their organization - and work better (Antonakis, Avolio \& Sivasubramaniam, 2003; Green, 2004; Shamir, House \& Arthur, 1993). Marketing instills values to brands, endowing them with a 'personality' going far beyond the technical and economic characteristics of a product (Fournier, 2003; McAlexander, Schouten \& Koenig, 2002; McCracken, 1989; Muniz \& O'Guinn, 2001; Plummer, 1984). A mere focus on economic dimensions seems therefore not adapted for studying and modeling the relations between a corporation and the numerous persons which whom it interacts (e.g., employees, customers...). 


\section{LIMITATIONS OF VALUE-NEUTRALITY IN MBP}

The second assumption, concerning the neutrality of science, was intended to shelter science from the influence of any socio-political group looking for misguiding 'scientific' justification for their ideas. But this neutrality does not imply that (1) scientists cannot or should not take a stand on issues concerning the broader society, nor does it imply that (2) scientific theories have no practical consequences or that scientists have no moral responsibility for the consequences of their theoretical reflections (M. Weber, 1965 [1917]; M. Weber, 1992 [1904], p. 129).

First, Popper, often considered as the father of modern science, affirms that the future is not predefined, but depends on the civic engagement of each citizen, including scientists (1993 [1989]; 2003 [1945], p. 307). His own engagement can be seen in The Open Society and Its Enemies (2003 [1943]; 2003 [1945]), in which he virulently criticizes Marxism, without however failing to dissociate scientific facts from philosophical argumentation (e.g., 2003 [1943], pp. 183-184) or personal beliefs (e.g., 2003

[1943], p. 189). Such engagement contrasts with MBP's tendency to neglect non-factual discussions concerning business and society (see the critic of the 'moral muteness' of managers in Bird \& Waters, 1989; see also Vranceanu, 2005). Business authors tend to draw normative conclusions from their models without investing in an broader ethical discussion of these norms and their practical implications (e.g., Bonardi \& Keim, 2005; McWilliams \& Siegel, 2001; see critically Montgomery, Wernerfelt \& Balakrishnan, 1989; Myrdal, 1984, p. 252). Most business models consequently lack "a critical guideline for corporate activities, showing how one can argue for the pros and cons of their ethical legitimacy" (Scherer \& Palazzo, 2007, forthcoming).

The second point - practical consequences of scientific theories - it best illustrated by the self-fulfilling prophecy effect. A self-fulfilling prophecy is a theory which was originally false but becomes true as people adapt their behavior to the theoretical model (Merton, 1959 [1948], p. 423). Such normative influence does not necessarily depend on the original empirical validity of the theory (Flynn, 2005; 
Généreux, 2001, p. 147; Gilbert, 1995); indeed, it often suffices that professors teach a specific model to their students for this model to be considered as the 'correct' norm of behavior (M. Weber, 1965 [1917], p. 373). Avoiding this influence is almost impossible as it is difficult, when presenting a model, "to find terms regarding social interaction that are without prescriptive value" (Gergen, 1973, p. 312). Researchers are in consequence not only observers of a specific reality, but also authors shaping it (Stengers, 1993). In recent years, different articles relied on the self-fulfilling prophecy concept in order to challenge the assumption that business science is 'value-free' (e.g., Cornelissen, 2005; Ferraro, et al., 2005; Ghoshal, 2005; Rocha \& Ghoshal, 2006, p. 587). In facts, many empirical observations tend to show the influence of MBP and its hypotheses on individuals, businesses, and society in general.

Influence on Individuals: Whereas the HE conception of MBP was originally conceived as an ideal type - a simplified concept neglecting many aspects of reality allowing the development of clear models (Friedman, 1953; M. Weber, 1965 [1917], pp. 425-426) -, this theoretical construct became over time a norm of behavior strongly influencing behavior in the business world and in society in general (Friedman, 1970; Jensen, 2002; Rees, 1985a, 1985b; see critically Bridel, 1999; Ghoshal \& Moran, 1996; Howard, 1985; Mintzberg, et al., 2002). Many individuals try to conform to this norm, even if they would prefer a different behavior (Miller \& Ratner, 1998; Ratner \& Miller, 2001), and the moral muteness of managers might partly be due to a desire to conform to the habits of their colleagues (Bird \& Waters, 1989; see also Pruzan, 2001). Consequently, more and more self-interested behavior can be observed; this behavior might however result less from human character as such and more from the conception of human character in business theory and the teaching of this concept at business schools (Marwell \& Ames, 1981; McCabe, et al., 2006; H. A. Klein, Levenburg, McKendall \& Mothersell, 2007)

Influence on the business system and on society: Whereas the HE hypothesis influences individual behavior, MBP's conception of free market competition as the best contributor to welfare (Friedman, 
1970; Williamson, 1975) shapes the structure of the business system and of society in general (Ferraro, et al., 2005; Ghoshal \& Moran, 1996; Ghoshal, Bartlett \& Moran, 1999). Friedman's assertion (1970) that shareholder value maximization increases freedom and market regulation reduces it implicitly shapes the structure of the socio-economic system. Firms tend for instance to reduce Friedman's own call for businesses to respect laws and ethical customs (1970, p. 122) to a (minimalist) compliance to legal obligations (Michael, 2006; Sharp Paine, 1994, 1996; Ulrich, 1986). Furthermore, a study of the Chicago Board Options Exchange - one of the first trade places focused on financial derivatives such as options - suggests that the rules prevailing in evaluating the price of the traded 'goods' is not merely the result of technological or legal changes, but "the effect of option pricing theory itself" (MacKenzie \& Millo, 2003, p. 137; see also Rainelli-Le Montagner, 2006). At the level of society, the global trend of liberalization can also be imputed to the influence of MBP (Stiglitz, 2002, 2003). Further, in the hope that free market and competition will enhance the quality of service while sinking costs, governments tend to entrust to private hands activities formerly reserved to public institutions. Every sixth prison in the U.S.A. is for instance 'managed' by a private company (Barber, 2000), and many functions previously reserved to military forces have been entrusted to commercial organizations in the Iraqi war (Rosemann, 2005). Finally, entrusting health care or education to private owners and free market (Gollust \& Jacobson, 2006) changes the perception of these 'commodities': If a sick person is considered as a client rather than as a patient, doctors might tend not to strive for the health of patient, but to ensure profit maximization (and healthy individuals are not profitable...). Similarly, if a strong performance logic is used to define the teachers' wages, it is probable that "teachers teach defensively, making sure their students will perform well on whatever tests will be used to evaluate their progress, at the expense of genuine education" (Schwartz, 1993, p. 182). The actual market economy and its values might therefore be the consequence of the 'mere theoretical' economic MBP (Firat, 1999; Polanyi, 1957 [1944], pp. 56-76). 


\section{LIMITATIONS OF SPECIALIZATION IN MBP}

Finally, the specialization assumption is challenged by some important changes in the societal context, which strengthen the impact of the self-fulfilling prophecy effect on behavioral norms. In the past, a strong common traditional framework provided cohesion in society and implicitly guided social interaction (Bell, 1976, p. 11; Lyotard, 1979, p. 7; Maffesoli, 2002, pp. 13-177). In consequence, specialization was implicitly limited by the fact that most members of the community - including scientists - shared a dense culture of common values and traditions (Gergen, 2000, pp. 201-206; Palazzo, 2005). This value framework set implicit boundaries to the autonomy of the different systems such as business or science. For instance, the HE concept already existed in theory, but the broader prosocial framework prevented a radical interpretation of egocentrism (Demeulenaere, 2003; Granovetter, 1985). Economic actors remained strongly embedded in their social context and the inherent traditional values (Hayek, 1949 [1945], p. 25; Hayek, 1984 [1983]), submitting profit maximization to "the basic rules of society, both that embodied in law and those embodied in ethical custom" (Friedman, 1970, p. 122; see also Berle \& Means, 2005 [1932]; Gonin, 2006). This implicit influence of the broader framework can also be observed in theory building itself. Smith's concept of economic self-interest (1981 [1776]) should for example not be disembedded from his broader study of people's more prosocial sentiments (1984 [1759]; see for example Meyer-Faje \& Ulrich, 1991; Blommestein, 2006).

This implicit traditional value framework has however been weakened in recent years. The universal validity of 'Western' values is questioned through globalization (Beck, 1992; Bindé, 2004; Giddens, 1994). The presence of many different cultures inside the Western world itself provides a plurality of worldviews and values out of which each individual is forced to build his/her own identity (Beck \& Lau, 2005; Lyotard, 1986). This worldviews competition lead to the fact that none of those worldviews - not even the traditional framework - can be considered as 'the right one' (Gergen, 2000, pp. 218-220; Giddens, 1991, p. 14; Lyotard, 1986; Maffesoli, 2004). As no strong normative framework exists with 
the required authority to set boundaries to the system- or role-specific values, MBP is no longer confronted with an external references implicitly framing the practical consequences of its theories.

In conclusion, whereas it was the fear of a tentative recuperation of science by some political ideology that led Weber, Merton, or Popper to call for a separation of science from the influence of the broader society, today's relation between science and society faces the opposite challenge. The embeddedness of business science in society and its increasing influence over it raises important issues concerning the civic duties of business scholars and the appropriateness of the assumptions.

\section{THE PARADOXES OF MBP}

As the context evolves, and mainstream business gains in normative authority, the actual relying of MBP on these assumptions seems to lead to some paradoxes.

The first paradox concerns the ambivalent relation of MBP toward the scientific rules. On the one hand, business research still claims to follow such noble rules. However, the 'disinterestedness' principle is challenged by the strong market-orientation of many business schools (Coy, Fischer \& Gordon, 2001; Karri, et al., 2005; Pfeffer \& Fong, 2004). Further, 'organized skepticism' seems not to work well as MBP remains the main paradigm in business science even though "during the last twenty-five years, economic theory has been proven systematically wrong" (Bazerman, 2005, p. 25).

The second paradox concerns the alleged value-neutrality. On the one hand, MBP clearly delineates its field of inquiry, focusing on rational means to reach 'given' goals, and assuming that the definition of these objectives lays outside the scope of economics and business (see critically Kliemt \& Ockenfels, 2004; Myers \& Papageorgiou, 1991; Yuengert, 2002). Scientific methodology is supposed to focus on facts, eluding questions concerning the normative value of theories (see critically Blommestein, 2006). On the other hand, the self-fulfilling prophecy effect confers MBP a tremendous normative impact on the goals of society and ways to quantify these objectives (e.g., Ferraro, et al., 2005). For instance, the implicit norms of efficiency and (mainly monetary) value-maximization become ends in themselves as 
they are the main criteria of evaluating many situations and behaviors. As many academic models use performance-oriented rather than more general welfare-oriented dependent variables (Walsh, Weber \& Margolis, 2003), it might be no surprise that measures of social welfare are often reduced to GDP (Cobb, Halstead \& Rowe, 1995; Nussbaum \& Sen, 1993), or that managers' wages are more and more based on economic performance and tend to ignore other criteria (Anderson, Cavanagh, Hartman, Klinger \& Chan, 2004; Jensen, 2002; see critically Fontrodona \& Sison, 2006; Gonin, 2006).

The strong influence of business theory on practice leads to the third paradox, concerning the specialization assumption. As mentioned above, MBP conceives the business system and the scientific institution as autonomous entities. This disembedded view of business research and practice tends to prevent constructive discussions about the role and responsibilities of business research and teaching in society (Blommestein, 2006). This 'moral muteness' of scientists - similar to the one Bird and Waters (1989) criticize in management - was not problematic as long as common traditional values implicitly shaped the interpretation and application of MBP. However, as the traditional framework erodes, business scientists cannot rely anymore on an implicit framing of their theories and of their application. Their model receive increasing authority, also outside the business world (Goudzwaard \& De Lange, 1995, pp. 95-96; Keim \& Zeithaml, 1986; Morton, 2006; Reich, 1998; Rondinelli, 2002). Lobbyists use for example strategies for influencing public decisions which are developed by business scholars (e.g., Bonardi \& Keim, 2005; Oliver, 1991). Further, globalization and modern technology allow multinational corporations to pressure states concerning social, environmental, and work-related issues (Chandler \& Mazlish, 2005; Rondinelli, 2002; Scherer, Palazzo \& Baumann, 2006; Young, 2004), and influence democracy (Habermas, 1996; Nussbaum, 2004; Scherer, et al., 2006; A. Sen, 1993, 1999; Van Parijs, 1995). In consequence, "precisely because scientific research is not conducted in a social vacuum, its effects ramify into other spheres of value and interest. Insofar as these effects are deemed socially undesirable, science is charged with responsibility" (Merton, 1973 [1938], p. 263). The border 
between business science and society becomes more and more blurry (Pels, 2003, p. 210; Granovetter, 1985; Polanyi, 1957 [1944], p. 57).

As the assumptions behind MBP seem no longer well adapted for describing today's relations between business and society, finding answers to the question of how to better align business schools' teaching with the values and expectations of society might begin by questioning these assumptions (Ghoshal, 2005) (Woolf, 1991).

\section{TOWARD A PARADIGM SHIFT: THE CIVIC RESPONSIBILITY OF BUSINESS SCHOLARS}

MBP's normative influence implies a specific responsibility for business scholars. Whereas in the past, readers of business journals or management students implicitly integrated MBP and its norms into a broader worldview, they have nowadays no strong framework which bridles the application of MBP. Therefore, promoting a disembedded view of MBP might encourage students or managers to analyze their social or economic environment and their behavior from a mere MBP perspective and ignore other criteria. Empirical studies for example show that economic students free ride more than other students (Marwell \& Ames, 1981) and are generally more tolerant toward cheating (McCabe, et al., 2006; H. A. Klein, et al., 2007).

Business schools therefore bear some important responsibilities concerning the promotion of the actually prevailing economic model, and its ethical downsides. Moreover, their strong influence confers them perhaps with the specific duty of using of this influence to shape tomorrow's business theory and practice and promote a conception of business which correspond to the expectations of the broader society. Making of this task a specific responsibility of business scholars implies however to challenge the actual assumptions. It becomes necessary (1) to recognize the empirical limitations of the actual mainstream business science methodology, (2) to reflect on normative issues concerning 
business theory and practice, and (3) to re-embed the business practice and research into the broader society. As MBP encourages the moral muteness of managers and the disembedding of the business world from the broader society (Bird \& Waters, 1989), business schools' best contribution to a better alignment of the business world on the values of the broader society is perhaps not some additional modules on ethics or morality or business-in-society (these are however also important); rather, business scholars could greatly contribute to promote civic virtues in business by radically changing the influential MBP paradigm. "Business schools do not need to do a great deal more to help prevent future Enrons; they need only to stop doing a lot they currently do." (Ghoshal, 2005, p. 75). A shift from the actual approach of business science - an imaginary neutrality bearing however concrete normative consequences - toward a paradigm allowing the normative discussion of the roles and responsibilities of businesses in society becomes necessary (Comte-Sponville, 2004, pp. 47-70; Merton, 1959 [1947], pp. 567-569; Stengers, 1993, p. 147; Vranceanu, 2005, p. 104; Yuengert, 2002).

In the second part of the article, I will sketch a new paradigm for discussing the role and responsibility of business scholars and business schools toward the broader society. To do so, I will look at how the Corporate Citizenship (CC) concept and Freeman's stakeholder theory can provide an alternative paradigm for defining the role and responsibility of business schools and business scholars.

\section{CORPORATE CITIZENSHIP AND STAKEHOLDER THEORY}

As the negative side effects of MBP became visible (see e.g., Unerman \& O'Dwyer, 2004; Williams, et al., 2000), MBP's disembedded conception of the business - society relations came under harsh criticism, both in the academic world and in society in general (Dobbs, 2006; Habermas, 1987, pp. 153197; N. Klein, 2001; Nussbaum \& Sen, 1993; Palazzo, 2002, pp. 134-146; Stiglitz, 2003). Different alternatives to this disembeddedness have been proposed, focusing on the rights and duties of corporations in society (for example the Corporate Citizenship concept) or on the numerous social groups with which firms interact (e.g., stakeholder theory). I will discuss these alternative conceptions 
of business - society relations, as they provide an interesting perspective for redefining the assumptions shaping the integration of societal expectations into business science.

Contrary to MBP conceiving corporations as disembedded profit-maximizing entities (Crook, 2005; Luhmann, 1984), corporate citizenship (CC) compares corporations to citizens bearing both rights and duties toward their social environment (Logsdon \& Wood, 2002; Matten \& Crane, 2005; Rondinelli, 2002; Rousseau \& Tijoriwala, 1998; Scherer \& Palazzo, 2007; Thompson \& Bunderson, 2003; Wood \& Logsdon, 2001). From a CC approach, accepting to submit - to some extent - corporate interests to higher societal norms is a condition for being granted the right to operate in society (L. Donaldson \& Dunfee, 1994; Ghoshal, et al., 1999; Ulrich, 2001; Valor, 2005). As these higher values also confer specific rights to stakeholders, a corporation is further requested to respect its stakeholders, i.e. all (groups of) individuals having some interests in the firm "whether the corporation has any corresponding interest in them" (T. Donaldson \& Preston, 1995, pp. 67, emphasis copied). These groups include economic partners such as customers, suppliers or shareholders, but also non-economic actors such as neighbors, NGOs, or political authorities (Freeman \& Reed, 1983; 2004).

As stakeholder theory and CC consider the firm as embedded in a broader social environment toward which it bears some responsibility, they imply a change in the MBP understanding of the corporations' role and responsibilities (T. Donaldson \& Preston, 1995; Scherer \& Palazzo, 2007). Furthermore, their conception of embeddedness challenge MBP assumptions and provide interesting insights for the definition of the place, role, and responsibility of business scholars in today's society, to be discussed in the next sections.

\section{ACADEMIC CITIZENSHIP}

In the first part of this article, I argued that business scholars tend nowadays to neglect the discussion of the practical implications of their models, arguing that scientific knowledge is separated from its normative impact on society, and relies on a specific methodology. This normative disembeddedness 
and the inherent limited responsibility of the scientific actor resembles the positions of MBP managers: As endorsers of specific roles, they focus only on the objectives defined by their role, and leave other roles and values aside (Friedman, 1970; Jensen, 2002). In business practice, this disembedded approach is being challenged by the CC approach. Similarly, I suggest that the mainstream disembedded approach of business science can be challenged by a concept of 'Academic Citizenship' (AC) - a vision of science that goes beyond research and publication, and includes responsibilities toward the broader community (Fallis, 2004; Popper, 2003 [1945], p. 232). Even if not mainstream yet, such embedded perspective of business theory has received more attention in recent years (Etzioni, 2003; Ghoshal, 2005; Mintzberg, 2004), and Sen (e.g., 1977; 1999) was even awarded the Nobel Prize in Economics (1998).

AC, by conferring new responsibilities to business scholars - i.e., to critically evaluate their models and their consequences in the light of social expectations - challenges the first assumption concerning methodological rules. It emphasizes that the broader population has some (legitimate) expectations toward the roles and responsibilities of scholars (Crettaz von Roten \& Leresche, 2004). Furthermore, by highlighting the civic responsibilities of scholars, AC challenges the second assumption which isolates the traditional objective-descriptive business science from a normative discussion of the model's compatibility with the expectations of the broader society (Swanson, 1999). Bridging this gap does not necessarily betray scientific neutrality, nor does it mean totally abandoning neutrality. It only implies that, as scientific neutrality is challenged by self-fulfilling prophecy effects, overtly discussing the normative influence of science becomes an important civic and scientific responsibility of scholars. Such analyze could provide a more objective (i.e., scientifically more valid) evaluation of the economic models and their consequences (T. Donaldson, 1994, p. 167; Mitroff, 1972; Ulrich, 2006; Werhane, 1994), and respond to the expectations of the broader society.

"To be scientific does not mean to be inhumanly free of all biases, assumptions, and preconceived notions and convictions. But, being scientific does require that one be aware of 
these and understand how they influence the way one structures one's research and the very way one perceives the resulting data." (Rosenthal \& Buchholz, 2000, p. 403)

Such normative discussion might take place at three levels. First, as serving public interest is part of the Academy of Managements' (AOM) mission, it might be important to start reflecting on the expectations of the society (Walsh, et al., 2003; see also Maréchal, 2001). Second, normatively discussing the frameworks - "the imagery, premises, and conceptualizations" (Stryker \& Vryan, 2003, p. 8) - underlying a theory might help understand its implicit and often value-laden assumptions (Bacharach, 1989; Vranceanu, 2005, p. 104; see already M. Weber, 1992 [1904], p. 123). Finally, knowing that self-fulfilling prophecy effects exist implies that scientists are responsible to anticipate the possible ethical or social consequences of the widespreading of their hypotheses and models (Manstetten, 2000, p. 120), especially if the latter could be proven wrong later (Giddens, 1991; Popper, 1978). Jonas' "imperative of responsibility" (1984), primarily thought for technological progress, needs perhaps to be adapted to social sciences: As models potentially bear negative consequences, it might be necessary to anticipate and discuss these consequences, both from a scientific and a civic perspective.

It is important to note that $\mathrm{AC}$ does by no way mean that research topics are to be defined by some instance outside science (neither by politics, nor by some 'expert committee') - such intervention would indeed threaten the important 'watchdog' role scientists are expected to assume. Rather, AC takes into account that the field of scientific work is well delineated - i.e. limited to studying fact - , and therefore ensures that other stakeholders can voice their hopes and fears when it comes to discussing values behind a specific model. Such discussion should in most cases suffice for identifying the dangers inherent to the normative influence of a model on society and consequently developing the necessary bridles to avoid them.

\section{STAKEHOLDER APPROACH OF BUSINESS SCIENCE}

In natural sciences, some important risks inherent to the widespreading of specific discoveries already led to society-wide debates concerning the application, and sometimes to restrictions, of specific 
research domains. The use of genetically modified organisms (GMO) has for example been largely discussed, leading to regulations considering not only the technological aspect, but also its ethical dimension or the expectations of the broader population (Frewer, et al., 2004). In social sciences, models such as MBP bear much less direct consequences; restrictions are therefore much less necessary. Nevertheless, it remains the responsibility of all citizens (if necessary through fair delegation), to discuss whether and how a scientific model is to be received and practically transformed into social norms (Manstetten, 2000, p. 29; Popper, 1993 [1989]; M. Weber, 1992 [1904], p. 123). The aim is not to sanction any theory, but to ensure transparent - even if controversial - information and discussions concerning models and their possible consequences. A stakeholder approach of business science challenges therefore the specialization assumption of MBP, as it underlines the importance of interactions between business science and the broader society. In this section, I will briefly identify the most important groups concerned with business research and teaching, as well as institutional tools which could facilitate the discussion between business scholars and these stakeholders.

Other fields of social sciences: Business research can hardly be isolated from other fields of social sciences. The primary stakeholders of business schools might therefore be social scientists. Economics is ultimately one field among others in social science; it "interpenetrates them all, and is reciprocally penetrated by them" (Hirshleifer, 1985, p. 53). Many research fields in business science also concern other fields of social sciences (Généreux, 2001; Montgomery, et al., 1989). For example, as the definition of the economic actor (i.e., the HE) deals with human nature and social interactions, it is as much the domain of anthropology and sociology as of economics; collaboration is therefore necessary for integrating the knowledge developed in the different fields into a coherent understanding of human nature (Hirshleifer, 1985, p. 53). In consequence, the time foreseen by Weber (1992 [1904], pp. 200201) might have come when mere scientific specialization might no longer be the best way to face new challenges. Collaboration with anthropologists, sociologists, and other social scientists becomes unavoidable (Manstetten, 2000, pp. 14-15). Furthermore, specialized researchers might have to 
collaborate with more 'generalist' scientists who focus on relationships between the different specific research field, in order to integrate the (still necessary) specialized knowledge into a broader framework (Laszlo, 1972, p. 12). Such integration seems indeed necessary both inside business science (Mitroff, 2004, p. 188; Seth \& Zinkhan, 1991) as between business science and other social sciences (Granovetter, 1985; Hirshleifer, 1985).

At structural level, the organization of interdisciplinary colloquia or conferences would help identify the numerous crossings between different research fields, and foster exchanges between them. Such exchange would contribute to the development of business models which do not contradict other research fields concerned by the model. Moreover, developing research and teaching partnership projects between business schools and social sciences faculties - e.g., creating a Master in Management and Social/Political Sciences - could facilitate long term collaboration between the different fields. Finally, recognizing the necessity of scholars who are more 'generalists' might imply the creation of chairs focusing on these interactions rather than specialized in a specific field. Journals are also needed in which articles less specialized or discussing can be published (Pfeffer, 2005; Walsh, et al., 2003); in addition, academic journals could promote the business-society discussion by requiring all articles to include a section discussing.

Economic Actors: Economic actors (such as managers, employees, shareholders, or consumers) represent the second key stakeholders for business science. Many managers, brokers, or shareholders apply the theories taught in business schools (Ferraro, et al., 2005; Ghoshal, 2005; MacKenzie \& Millo, 2003; Mintzberg, 2004). Furthermore, the specific situations and challenges encountered by managers can - should? - be source of future research questions (e.g., Ford, et al., 2003). But managers are not the only one concerned: Consumers of products or of services are also concerned by business theories. They apply (not as often as economic theory supposes...) economic rationality; and it does matter for them whether a business model considers them "as ends in themselves" - i.e. primarily citizens with some rights - or as "means to the end" - i.e. mere tools for profit-maximization (Garrett, 1987, p. 268). 
A broad stakeholder dialog could help align business research with the expectations of the different actors in business, and consequently develop models that practically serve public interest (Seth \& Zinkhan, 1991)

Different structures can be created to foster the dialog with economic stakeholders, such as (Ford, et al., 2003): workshops co-sponsored by academic and non-academic partners, collaboration with practitioners in some research projects, or long-term follow-up of the practical implementation of theories. Stakeholder theory further emphasizes the importance that all actors can be heard in these discussions platforms - multinational corporations as well as consumers such as small grocery customers or individual bank account holders (see T. Donaldson \& Preston, 1995).

The Civil Society: Last but not least, the discussion on the aim of business science - what should economic models and management theories be developed for? - concerns all actors of society (Yuengert, 2002). As this issue is closely related to the values of the broader society, it might be useful for business scholars to discuss this question with many different stakeholders. In Switzerland for example, $57 \%$ of the population desire that scientists engage in broader dialogues (Crettaz von Roten \& Leresche, 2004). As such broader debate take place outside the specific sphere of science, scientists have no more power than other stakeholders in the discussion, and their 'truth' is confronted with other 'truths' (Stengers, 1993, p. 182; see also Comte-Sponville, 1997, p. 11; Généreux, 2001, p. 153; Habermas, 2001; Latour, 1991, pp. 194-198; Pels, 2003; Rothberg, 2000; Touraine, 1994, p. 29). Society is never forced to morally like what science says, even if it seems scientifically 'true' (Aron, 1959, p. 15).

Different institutional tools can be used in order to better align business research with the expectations of the broader population, such as public lectures, empirical studies of the population's expectations, or the participation of faculty members in different public arenas. But foremost, it might be the duty of each scholar to remain informed of the actual challenges of the broader population, and to reflect on how he/she can best contribute to solving the most urgent economic challenges. 
Many other stakeholders of business science could be mentioned in this list, such as the 'environment' (The Economist, 2006; Zyglidopoulos, 2002) or families (work-family issue is a recurrent topic in Human Resources literature, see e.g., Frame \& Hartog, 2003; Lobel, 1991). Drawing a more precise map of the stakeholders' expectations is however out of the scope of this paper and must be left to future research.

In summary, a citizenship and stakeholder approach of business science focuses on re-embedding business science in the broader societal context and on the civic responsibilities of scholars for their research and teaching. It challenges the MBP assumptions, and might imply a paradigm change. Such change necessitates the engagement of scholars from all fields of business (and of social scientists, as more collaboration will be necessary). It requires all business scholars to confront their work with the expectations of the broader society; such confrontation could greatly serve public interest, as it could result in developing a business model better adapted to today's societal context.

Furthermore, changing the paradigm implies numerous changes in the actual mainstream business education. The new paradigm indeed focuses not on specialized classes, but on an integrative and reflective approach of business and society. The last section of this article will discuss possible adaptations in business education which could promote the new paradigm presented above.

\section{THE NEW PARADIGM AND EDUCATION}

Since the ethical scandals of Enron or Worldcom (e.g. ,Ghoshal, 2005; Unerman \& O'Dwyer, 2004), a broad discussion is taking place concerning the responsibility business education in these ethical downsides. Business-in-society lectures and ethics classes have also been added to most business curricula (Weiss, 2006), and some schools organize ethics awareness weeks discussing the ethical dimensions of the theories taught in all management or economics classes (Spain, Engle \& Thompson, 2005). Others schools go one step further and try, next to traditional ethics classes, to integrate ethical reasoning in all classes as well as in the school's culture (J. Weber, 2006; Weiss, 2006). 
However, it seems that it does not yet suffice for balancing the disembedded and morally mute concept of business taught in the other classes (Boyce, 2006; Koehn, 2005; Spain, et al., 2005). The fact that most lectures focus on specific topics, inherent to the specialized research methodology, seems not well adapted for preparing students to the highly complex and interconnected business world (Bennis \& O'Toole, 2005; Castro, 1994, p. 189; Kanter, 2005; Mintzberg, 2004; Mitroff, 2004). MBP tends to form students - that is, future researchers or workers - which are lacking the capacity of critically including into their decisions many different types of information (technical, financial, social, political, moral, environmental...) (Carrithers \& Peterson, 2006; Mintzberg, 2004, p. 31; Pfeffer \& Fong, 2002). Such traditional curricula rely on the specialization and value-neutrality assumptions criticized above. Therefore, based on the critics made above toward MBP and on the alternative model proposed, I argue that solving the problem of the disembeddedness of management practices from a broader ethical discussion does not rely on adding some courses in ethics or business-in-society. Rather, I suggest that a new curriculum which considers business education as something embedded in a broader perspective (Pfeffer \& Fong, 2002) has to become mainstream. In order to take into account the complexity and embeddedness of business into the broader society, the new teaching paradigm would probably have to offer a multidisciplinary approach focusing on philosophies and mindsets behind techniques rather than techniques themselves (Pfeffer \& Fong, 2002; Mintzberg, 2004). Management lectures would have to be integrated into a curriculum in which "the whole fabric of an organization's existence, including its societal, cultural, and political contexts, provides the core of the curriculum, and economic analysis finds its place within this context" (Etzioni, 1991, p. 350).

In order to respect the citizenship and stakeholder approach of business developed in this article, the new business curriculum might have to focus (1) on the critical thinking aptitudes of future managers rather than on too narrow methodologies, (2) on the civic responsibilities of managers inherent to their belonging to a specific community rather than on the no longer possible value-neutrality, and (3) on the multiple interactions with the different stakeholders rather than on mere specialization. Rather than 
teaching specific 'techniques' (e.g., marketing or accounting techniques), it might be more adapted to focus on developing critical thinking, as well as knowledge about oneself and about his/her interactions with the organization, culture, and global context (see the curriculum proposition of Mintzberg, 2004). The curriculum should provide enough time and a broad panel of tools in order to critically discuss management theories and the business-in-society issue (see e.g., Carrithers \& Peterson, 2006; McVea, 2007; Mintzberg, 2004), rather than proposing too much specialized lectures so that "time and energy are taken up by learning more and more facts so that there is little left for thinking" (Fromm, 1977 [1942], p. 214). The capacity to take some distance to critically analyze one's situation or the consequences of one's decision, as well as to reflect on the expectations of the broader society, might indeed become important for managers in a more and more complex environment (Coy, et al., 2001; Maak \& Pless, 2006; Painter-Morland, 2006; Valor, 2005; Woolf, 1991). Finally, as business theory and practice are embedded in the broader society, business teachers also bear the civic responsibility to encourage their students to look at how they can best serve public interest. This does not mean that they should always promote the ideology prevailing in their socio-political context. On the contrary, they should form students to critically assess the different worldviews surrounding them, and prepare them to fight for those worldviews which seems to contribute at best to the future development of their (nowadays global?) community. Such engagement could be symbolized by some kind of 'Hippocratic oath' for managers which highlights the responsibility of business graduates for the greater good (Darrow, 2006; see also the - minimalist - Graduation Pledge in Reiter, 2000).

\section{CONCLUSION}

This article shows how, through changes in society and the self-fulfilling prophecy effect, MBP has become a strong behavioral norm for those acting in the business community and even outside. Therefore, business scholars bear an important responsibility for the models they develop and teach. I do not aim at throwing stones to any past or present research, but rather to see which lessons can be 
learned from the unintended and often ignored normative influence of business science, in order to avoid making similar mistakes and anticipate tomorrow's challenges (see Blaug, 2001).

The fact that pure objectivity and disembeddedness is not possible for business science should not be seen as a failure; rather, it should be accepted as an empirical fact, and perhaps considered as a chance and a responsibility to contribute to the construction of tomorrow's society. If self-fulfilling prophecy led to the actual mainstream business practice, one can hope that it will also help the alternative paradigm presented in this article to gain mainstream in practice (see Pfeffer, 2005). Researchers can change the course of history; they have to accept it and consider it as both a chance and a great civic responsibility. Contrary to Luhmann's assertion (1982), business science remains embedded in a broader objective of justice or freedom, and its influence on society implies a responsibility.

Redefining the moral duties of business scholars or the place of business schools in society therefore starts by questioning the assumptions which led to the actual situation. Understanding that MBP seems to prevent any lasting embedding of business theory and practice into the broader societal framework is indeed not without consequence. It implies that it is probably more efficient to develop an alternative paradigm to MBP, rather than trying to solve its numerous problems. More than developing efficient 'business-in-society' classes or ethics awareness weeks', a change in organizational culture needs to be instilled for business schools to better serve public interest (Sims \& Brinkmann, 2003; Whetstone, 2005). If we want future managers to critically look at themselves, at their work, and at their roles and responsibility, we need to be ourselves "more truly members of our own universities, more seriously responsible to our students and our colleagues, and more conscious of the costs associated with the bureaucratic compartmentalization within our own precincts" (Castro, 1994, p. 189). The citizenship roots of any scientists should encourage him/her to go and meet the numerous stakeholders in order to discuss the serious issues of the aims and fundamental values on which business models should be built. In order to be coherent, scholars who criticize the dichotomy of some managers who isolate their managers roles from the rest of their roles and values in society also need to criticize business 
researchers who separate their scientific role from the rest, especially when negative side effects are to be expected. Weber's (1992 [1904], p. 129) or Popper's calls (2003 [1945], p. 232) for scientists who at the same time can recognize scientific facts and fight for their ideals might be urgent again. Tomorrow's business system and societal structures depends (in part) on us!

\section{ACKNOWLEDGMENT}

The author wants to thank Guido Palazzo for his precious comments on earlier versions of the paper.

\section{REFERENCES}

Anderson, S., Cavanagh, J., Hartman, C., Klinger, S. \& Chan, S. (2004), Executive Excess 2004. Campaign Contributions, Outsourcing, Unexpensed Stock Options and Rising CEO Pay. (Washington: Institute for Policy Studies), retrieved 2007-05-11 from http://faireconomy.org/press/2001/EE2001.pdf

Antonakis, J., Avolio, B. J. \& Sivasubramaniam, N. (2003). Context and leadership: an examination of the nine-factor full-range leadership theory using the multifactor leadership questionnaire. Leadership Quarterly, 14(3), 261-295

Argyris, C. (1976). Leadership, learning, and changing the status quo. Organizational Dynamics, 4(3), $29-43$

Aron, R. (1959). Introduction (In M. Weber (Ed.), Le savant et le politique (pp. 9-57). Paris: Plon)

Bacharach, S. B. (1989). Organizational theories: Some criteria for evaluation. Academy of Management Review, 14(4), 496-515

Barber, B. R. (2000). Can democracy survive globalization. Government and Opposition, 35(3), 275301

Bazerman, M. H. (2005). Conducting influential research: The need for prescriptive implications. Academy of Management Review, 30(1), 25-31

Béchard, J.-P. \& Grégoire, D. (2005). Entrepreneurship education research revisited: The case of higher education. Academy of Management Learning \& Education, 4(1), 22-43

Beck, U. (1992), Risk Society: Towards a New Modernity. (London, Newbury Park CA, New Delhi: Sage) 
Beck, U. \& Lau, C. (2005). Second modernity as a research agenda: Theoretical and empirical explorations in the 'meta-change' of modern society. British Journal of Sociology, 56(4), 525-557

Bell, D. (1976), The Cultural Contradictions of Capitalism. (London: Heinemann)

Benefiel, M. (2005), Soul at Work. Spiritual Leadership in Organizations. (New York: Seabury Books)

Bennis, W. G. \& O'Toole, J. (2005). How business schools lost their way. Harvard Business Review, 83(5), 96-104

Berle, A. A. \& Means, G. C. (2005 [1932]), The Modern Corporation \& Private Property. 3rd edition. (London: Transaction Publishers)

Bindé, J. (Ed.): (2004). The Future of Values. (Paris: UNESCO)

Bird, F. B. \& Waters, J. A. (1989). The moral muteness of managers. California Management Review, 32(1), 73-88

Blaug, M. (2001). No History of Ideas, Please, We're Economists. Journal of Economic Perspectives, $15(1), 145-164$

Blommestein, H. J. (2006). Why is ethics not part of modern economics and finance? A historical perspective. Finance \& the Common Good / Bien Commun(24), 54-64

Bonardi, J.-P. \& Keim, G. D. (2005). Corporate political strategies for widely salient issues. Academy of Management Review, 30(3), 555-576

Boyce, G. (2006). The social relevance of ethics education in a global(ising) era: From individual dilemmas to systemic crisis. Critical Perspectives on Accounting, forthcoming

Bridel, P. (1999). Homo oeconomicus: rerum cognoscere causas? ou du principe de rationalité comme instrument de connaissance en théorie économique. Revue européenne des sciences sociales, 37(113), 149-167

Buchholz, R. A. \& Rosenthal, S. B. (2005). The spirit of entrepreneurship and the qualities of moral decision making: Toward a unifying framework. Journal of Business Ethics, 60(3), 307-315

Cagle, J. A. B. \& Baucus, M. S. (2006). Case studies of ethics scandals: Effects on ethical perceptions of finance students. Journal of Business Ethics, 64(3), 213-229

Carrithers, D. F. \& Peterson, D. (2006). Conflicting views of markets and economic justice: Implications for students learning. Journal of Business Ethics, 69(4), 373-387

Castro, B. (1994). Business ethics: knowing ourselves. Business Ethics Quarterly, 4(2), 181-190

Chalmers, A. F. (1987), Qu'est-ce que la science? Popper, Kuhn, Lakatos, Feyerabend. (Paris: La Découverte) 
Chandler, A. D. \& Mazlish, B. (2005). Introduction (In A. D. Chandler \& B. Mazlish (Eds.), Leviathans. Multinational Corporations and the New Global History (pp. 1-15). Cambridge: Cambridge University Press)

Cobb, C., Halstead, T. \& Rowe, J. (1995). If GDP is up, why is America down? The Atlantic, 276(4), $59-78$

Comte-Sponville, A. (1997). Entretien avec André Comte-Sponville (In H. Reeves (Ed.), Intimes convictions (pp. 7-22). Vénissieux: Paroles d'Aube)

Comte-Sponville, A. (2004), Le Capitalisme est-il Moral? (Paris: Albin Michel)

Conlin, M. (1999). Religion in the workplace. Business Week(3653), 151-158

Cornelissen, J. P. (2005). Beyond compare: Metaphor in organization theory. Academy of Management Review, 30(4), 751-764

Coy, D., Fischer, M. \& Gordon, T. (2001). Public accountability: A new paradigm for college and university annual reports. Critical Perspectives on Accounting, 12, 1-31

Crettaz von Roten, F. \& Leresche, J.-P. (2004). Science, technique et opinion publique en Suisse. in J.P. Leresche (ed.), Cahiers de l'Observatoire (Lausanne: Observatoire Science, Politique et Société)

Crook, C. (2005). The good company. The Economist, 374(8410), 3-18

Darrow, J. (2006). How Can I Be Expected to Understand All This? A discussion around the role of business education in shaping business responsibility in the knowledge economy (In The Ashridge Best European MBA Essay Award (Ed.), The Responsibilities of Business in a Knowledge Economy (p no pages). Milano: EABIS)

Demeulenaere, P. (2003), Homo Oeconomicus. Enquête sur la constitution d'un paradigme. (Paris: Presses Universitaires Françaises)

Dobbs, L. (2006), War on the Middle Class. How the Government, Big Business, and Special Interest Groups Are Waging War on the American Dream and How to Fight Back. (New York: Viking)

Donaldson, L. (2005). For positive management theories while retaining science: Reply to Ghoshal. Academy of Management Learning \& Education, 4(1), 109-113

Donaldson, L. \& Dunfee, T. W. (1994). Toward a unified conception of business ethics: Integrative social contracts theory. Academy of Management Review, 19(2), 252-284

Donaldson, T. (1994). When integration fails: The logic of prescription and description in business ethics. Business Ethics Quarterly, 4(2), 157-169

Donaldson, T. \& Preston, L. E. (1995). The stakeholder theory of the corporation: Concepts, evidence, and implications. Academy of Management Review, 20(1), 65-91 
Dubbink, W. (2004). The fragile structure of free-market society. The radical implications of corporate social responsibility. Business Ethics Quarterly, 14(1), 23-46

Dubin, R. (1976). Theory building in applied areas (In M. D. Dunette (Ed.), Handbook of Industrial and Organizational Psychology (pp. 17-39). Chicago: Rand McNally)

Englis, B. G. \& Solomon, M. R. (1997). I am not ... therefore I am: The role of avoidance products in shaping consumer behavior. Advances in Consumer Research, 24, 61-63

Etzioni, A. (1991). Socio-economics. The next steps (In A. Etzioni \& P. R. Lawrence (Eds.), SocioEconomics. Toward a New Synthesis (pp. 347-352). Armonk NY and London: M.E. Sharpe)

Etzioni, A. (2003). Toward a new socio-economic paradigm. Socio-Economic Review, 1, 105-134

Fallis, G. (2004). The Mission of the University (Toronto: York University, Department of Economics and Division of Social Science), retrieved 2007-05-11 from http://www.cou.on.ca/content/objects/The\%20Mission\%20V3.pdf

Fehr, E. \& Gächter, S. (2002). Altruistic punishment in humans. Nature, 415(6868), 137-140

Ferraro, F., Pfeffer, J. \& Sutton, R. I. (2005). Economics language and assumptions: How theories can become self-fulfilling. Academy of Management Review, 30(1), 8-24

Feyerabend, P. (1987), Farewell to Reason. (New York \& London: Verso)

Firat, A. F. (1999). Rethinking Consumption. Consumption, Markets and Culture, 3(4), 283-295

Flynn, F. J. (2005). Identity orientations and forms of social exchange in organizations. Academy of Management Review, 30(4), 737-750

Fontrodona, J. \& Sison, A. J. G. (2006). The nature of the firm, agency theory and shareholder theory: A critique from philosophical anthropology. Journal of Business Ethics, 66(1), 33-42

Ford, E. W., Duncan, J., Bedeian, A. G., Ginter, P. M., D., R. M. \& Adams, A. M. (2003). Mitigating risks, visible hands, inevitable disasters, and soft variables: Management research that matters to managers. Academy of Management Executive, 17(1), 46-60

Fournier, S. (2003). Consumers and their brands: Developing relationship theory in consumer research. Journal of Consumer Research, 24(4), 343-373

Frame, P. \& Hartog, M. (2003). From rhetoric to reality. Into the swamp of ethical practice: implementing work-life balance. Business Ethics: A European Review, 12(4), 358-368

Freeman, R. E. \& Reed, D. L. (1983). Stockholders and stakeholders: A new perspective on corporate governance. California Management Review, 25(3), 88-106

Freeman, R. E., Wicks, A. C. \& Parmar, B. (2004). Stakeholder theory and "The corporate objective revisited". Organization Science, 15(3), 364-369 
Frewer, L., Lassen, J., Kettlitz, B., Scholderer, J., Beekman, V. \& Berdal, K. G. (2004). Societal aspects of genetically modified foods. Food and Chemical Toxicology, 42(7), 1181-1193

Friedman, M. (1953). The methodology of positive economics (In M. Friedman (Ed.), Essays in Positive Economics (pp. 3-43). Chicago: University of Chicago Press)

Friedman, M. (1970). The Social Responsibility of Business Is to Increase Its Profits, New York Times Magazine, 1970-09-13, pp. 122-126

Fromm, E. (1977 [1942]), The Fear of Freedom. (London and Henley: Routledge \& Kegan Paul)

Garrett, D. E. (1987). The effectiveness of marketing policy boycotts: Environmental opposition to marketing. Journal of Marketing, 51(2), 46-57

Généreux, J. (2001). Manifeste pour l'économie humaine. Esprit, 2001(7), 141-170

Gergen, K. J. (1973). Social psychology as history. Journal of Personality and Social Psychology, 26(2), 309-320

Gergen, K. J. (2000), The Saturated Self. Dilemmas of Identity in Contemporary Life. 2nd edition. (New York: Basic Books)

Ghoshal, S. (2005). Bad management theories are destroying good management practices. Academy of Management Learning \& Education, 4(1), 75-91

Ghoshal, S., Bartlett, C. A. \& Moran, P. (1999). A new manifesto for management. Sloan Management Review, 40(3), 9-20

Ghoshal, S. \& Moran, P. (1996). Bad for practice: A critique of the transaction cost theory. Academy of Management Review, 21(1), 13-47

Giddens, A. (1991), Modernity and Self-Identity. Self and Society in the Late Modern Age. (Cambridge: Polity Press)

Giddens, A. (1994). Living in a Post-Traditional Society (In U. Beck, A. Giddens \& S. Lash (Eds.), Reflexive Modernization. Politics, Tradition and Aesthetics in the Modern Social Order (pp. 56109). Cambridge: Polity Press)

Gilbert, D. T. (1995). Attribution and interpersonal perception (In A. Tesser (Ed.), Advanced Social Psychology (pp. 99-147). Boston, MA: McGraw Hill)

Gollust, S. E. \& Jacobson, P. D. (2006). Privatization of public services: organizational reform efforts in public education and public health. American Journal of Public Health, 96(10), 1733-1739

Gonin, M. (2006). Die Trennung des Unternehmens vom Bürger - eine historisch-kritische Perspektive (In E. Patry \& P. Ulrich (Eds.), Marktwirtschaft als Teil einer bürgergesellschaftlichen Gesamtordnung (pp. 41-56). St. Gallen: Institut für Wirtschaftsethik der Universität St. Gallen) 
Goudzwaard, B. \& De Lange, H. (1995), Beyond Poverty and Affluence. Toward an Economy of Care With a Twelve-Step Program for Economic Recovery. (Geneva: World Council of Churches Publications)

Granovetter, M. (1985). Economic action and social structure: The problem of embeddedness. The American Journal of Sociology, 91(3), 481-510

Green, S. E., Jr. (2004). A rhetorical theory of diffusion. Academy of Management Review, 29(4), 653669

Habermas, J. (1987), The Theory of Communicative Action. Volume Two: Lifeworld and System: A critique of Functionalist Reason. (Boston, MA: Beacon Press)

Habermas, J. (1996), Between Facts and Norms. Contributions to a Discourse Theory of Law and Democracy. (Cambridge, MA: MIT Press)

Habermas, J. (2001), Glauben und Wissen. (Frankfurt am Main: Suhrkamp), retrieved 2007-05-11 from http://www.glasnost.de/docs01/011014habermas.html

Hayek, F. A. v. (1937). Economics and knowledge. Economica, 4(13), 33-54

Hayek, F. A. v. (1949 [1945]). Individualism: True and false (In F. A. v. Hayek (Ed.), Individualism and Economic Order (pp. 1-32). London: Routledge)

Hayek, F. A. v. (1984 [1973]). Principles and expediency (In C. Nishiyama \& K. R. Leube (Eds.), The Essence of Hayek (pp. 299-317). Stanford: Hoover Institution Press)

Hayek, F. A. v. (1984 [1983]). The origins and effects of our morals: A problem for science (In C. Nishiyama \& K. R. Leube (Eds.), The Essence of Hayek (pp. 318-330). Stanford: Hoover Institution Press)

Herrnstein, R. J. (1993). Behavior, reinforcement, and utility (In M. Hechter, L. Nadel \& R. E. Michod (Eds.), The Origin of Values (pp. 137-152). New York: Aldine De Gruyter)

Hira, A. \& Ferrie, J. (2006). Fair trade: Three key challenges for reaching the mainstream. Journal of Business Ethics, 63(2), 107-118

Hirshleifer, J. (1985). The expanding domain of economics. American Economic Review, 53(6), 53-68

Howard, G. S. (1985). The role of values in the science of psychology. American Psychologist, 40(3), 255-265

Jensen, M. C. (2002). Value maximization, stakeholder theory, and the corporate objective function. Business Ethics Quarterly, 12(2), 235-256

Jensen, M. C. \& Meckling, W. H. (1976). Theory of the firm: Managerial behavior, agency costs and ownership structure. Journal of Financial Economics, 3(4), 305-360

Jonas, H. (1984), The Imperative of Responsibility. (Chicago: University of Chicago Press) 
Kanter, R. M. (2005). What theories do audiences want? Exploring the demand side. Academy of Management Learning \& Education, 4(1), 93-95

Karri, R., Caldwell, C., Antonacopoulou, E. P. \& Neagle, D. (2005). Building trust in business schools through ethical governance. Journal of Academic Ethics, 3(2-4), 159-182

Keim, G. D. \& Zeithaml, C. P. (1986). Corporate political strategy and legislative decision making: A review and contingeny approach. Academy of Management Review, 11(4), 828-843

Klein, H. A., Levenburg, N. M., McKendall, M. \& Mothersell, W. (2007). Cheating during the college years: How do business school students compare. Journal of Business Ethics, 72(2), 197-206

Klein, N. (2001), No logo: la tyrannie des marques: essai. (Arles: Actes Sud)

Kliemt, H. \& Ockenfels, A. (2004). A dialogue concerning the nature of rationality (In S. Huck (Ed.), Advances in Understanding Strategic Behavior: Game Theory, Experiments and Bounded Rationality. Essays in Honor of Werner Güth (pp. 105-119). Houndmills: Palgrave)

Koehn, D. (2005). Transforming our students: Teaching business ethics post-Enron. Business Ethics Quarterly, 15(1), 137-151

Kozinets, R. V. \& Handelman, J. M. (2004). Adversaries of consumption: consumer movements, activism, and ideology. Journal of Consumer Research, 31, 691-704

Kuhn, T. S. (1970). Reflexions on my critics (In I. Lakatos \& A. Musgrave (Eds.), Criticism and the Growth of Knowledge (pp. 231-278). London, New York: Cambridge University Press)

Kuhn, T. S. (1972), La structure des révolutions scientifiques. (Paris: Flammarion)

Lakatos, I. (1978), The methodology of scientific research programmes. Philosophical Papers. (Cambrige, London, New York, Melbourne: Cambridge University Press)

Laszlo, E. (1972), The Systems View of the World. (Oxford: Basil Blackwell)

Latour, B. (1991), Nous n'avons jamais été modernes. Essai d'anthropologie symétrique. (Paris: La Découverte)

Levitt, T. (1958). The dangers of social responsibility. Harvard Business Review, 36(5), 41-50

Lobel, S. A. (1991). Allocation of investment in work and family roles: Alternative theories and implications for research. Academy of Management Review, 16(3), 507-521

Logsdon, J. M. \& Wood, D. J. (2002). Business citizenship: From domestic to global level of analysis. Business Ethics Quarterly, 12(2), 155-187

Lopez, Y. P., Rechner, P. L. \& Olson-Buchanan, J. B. (2005). Shaping ethical perceptions: An empirical assessment of the influence of business education, culture, and demographic factors. Journal of Business Ethics, 60(4), 341-358

Luhmann, N. (1982), The Differentiation of Society. (New York: Columbia University Press) 
Luhmann, N. (1984). Die Wirtschaft der Gesellschaft als autopoietisches System. Zeitschrift für Soziologie, 13(4), 308-327

Lye, A., Shao, W. \& Rundle-Thiele, S. (2005). Decision waves: Consumer decision in today's complex world. European Journal of Marketing, 39(1/2), 216-230

Lyotard, J.-F. (1979), La condition postmoderne. Rapport sur le savoir. (Paris: Les éditions de Minuit)

Lyotard, J.-F. (1986). Defining the Postmodern, Postmodernism (pp. 6-7). London: Institute of Contemporary Arts Publications)

Maak, T. \& Pless, N. M. (2006). Responsible leadership in a stakeholder society - A relational perspective. Journal of Business Ethics, 66(1), 99-115

MacKenzie, D. \& Millo, Y. (2003). Constructing a market, performing theory: The historical sociology of a financial derivatives exchange. American Journal of Sociology, 109(1), 107-145

Maffesoli, M. (2002), La transfiguration du politique. La tribalisation du monde postmoderne. 3e edition. (Paris: La Table Ronde)

Maffesoli, M. (2004). Vers une éthique postmoderne de l'esthétique? (In J. Bindé (Ed.), Où vont les valeurs? (pp. 119-124). Paris: UNESCO - Albin Michel)

Manstetten, R. (2000), Das Menschenbild der Ökonomie. Der homo oeconomicus und die Anthropologie von Adam Smith. (Freiburg \& München: Verlag Karl Alber)

Maréchal, J.-P. (2001). Critique d'un lieu commun: l'économie comme science. Esprit, 2001(7), 129140

Marwell, G. \& Ames, R. E. (1981). Economists free ride, does anyone else? Experiments on the provision of public goods, IV. Journal of Public Economics, 15(3), 295-310

Matten, D. \& Crane, A. (2005). Corporate citizenship: Toward an extended theoretical conceptualization. Academy of Management Review, 30(1), 166-179

McAlexander, J., H., Schouten, J. W. \& Koenig, H. F. (2002). Building brand community. Journal of Marketing, 66, 38-54

McCabe, D. L., Butterfield, K. D. \& Trevino, L. K. (2006). Academic dishonesty in graduate business programs: Prevalence, causes, and proposed action. Academy of Management Learning \& Education, 5(3), 294-308

McCracken, G. (1989). Who is the Celebrity Endorser? Cultural Foundations of the Endorsement Process. Journal of Consumer Research, 16(3), 310-321

McVea, J. F. (2007). Constructing good decisions in ethically charged situations: The role of dramatic rehearsal. Journal of Business Ethics, 70(4), 375-390 
McWilliams, A. \& Siegel, D. (2001). Corporate social responsibility: A theory of the firm perspective. Academy of Management Review, 26(1), 117-127

McWilliams, A., Siegel, D. \& Wright, P. M. (2006). Corporate social responsibility: Strategic implications. Journal of Management Studies, 43(1), 1-18

Merton, R. K. (1959 [1947]). The machine, the worker and the engineer (In R. K. Merton (Ed.), Social Theory and Social Structure (pp. 562-573). New York: The Free Press)

Merton, R. K. (1959 [1948]). The self-fulfilling prophecy (In R. K. Merton (Ed.), Social Theory and Social Structure (pp. 421-436). New York: The Free Press)

Merton, R. K. (1968). The Matthew effect in science. Science, 159(3810), 56-63

Merton, R. K. (1973 [1938]). Science and the social order (In R. K. Merton \& N. W. Storer (Eds.), The Sociology of Science. Theoretical and Empirical Investigations (pp. 254-266). Chicago: University of Chicago Press)

Merton, R. K. (1973 [1942]). The normative structure of science (In R. K. Merton \& N. W. Storer (Eds.), The Sociology of Science. theoretical and Empirical Investigations (pp. 267-278). Chicago: University of Chicago Press)

Meyer-Faje, A. \& Ulrich, P. (Eds.) (1991). Der andere Adam Smith. Beiträge zur Neubestimmung von Ökonomie als Politischer Ökonomie. (Vol. 5). (Bern, Stuttgart, \& Wien: Haupt)

Michael, M. L. (2006). Business ethics: The law of rules. Business Ethics Quarterly, 16(4), 475-504

Miller, D. T. \& Ratner, R. K. (1998). The disparity between the actual and assumed power of selfinterest. Journal of Personality and Social Psychology, 74(1), 53-62

Mintzberg, H. (2004), Managers Not MBAs. A Hard Look at the Soft Practice of Managing and Management Development. (London et al.: Prentice-Hall)

Mintzberg, H., Simons, R. \& Basu, K. (2002). Beyond selfishness. Sloan Management Review, 44(1), $67-74$

Mitroff, I. I. (1972). The myth of objectivity or why science needs a new psychology of science. Management Science, 18(10), B-613 - B-618

Mitroff, I. I. (2004). An open letter to the deans and the faculties of American Business Schools. Journal of Business Ethics, 54(2), 185-189

Montgomery, C. A., Wernerfelt, B. \& Balakrishnan, S. (1989). Strategy content and the research process: A critique and commentary. Strategic Management Journal, 10(2), 189-197

Morton, D. (2006). Gunning for the world. Foreign Policy(152), 58-67

Muniz, A. M., Jr. \& O'Guinn, T. C. (2001). Brand Community. Journal of Consumer Research, 27(4), $412-432$ 
Myers, G. M. \& Papageorgiou, Y. Y. (1991). Homo economicus in perspective. The Canadian Geographer, 35(4), 380-399

Myrdal, G. (1984). Implicit values in economics (In D. M. Hausman (Ed.), The Philosophy of Economics (pp. 250-258). Cambridge: Cambridge University Press)

Nisan, M. (1993). Balanced identity: Morality and other identity values (In G. G. Noam \& T. E. Wren (Eds.), The Moral Self (pp. 239-266). Cambridge: MIT Press)

Nussbaum, M. C. (2004). Beyond the social contract: capabilities and global justice. An Olaf Palme Lecture, delivered in Oxford on 19 June 2003. Oxford Development Studies, 32(1), 3-18

Nussbaum, M. C. \& Sen, A. (Eds.) (1993). The Quality of Life. (Oxford: Clarendon Press)

Oliver, C. (1991). Strategic responses to institutional processes. Academy of Management Review, $16(1), 145-179$

Painter-Morland, M. (2006). Redefining accountability as relational responsiveness. Journal of Business Ethics, 66(1), 89-98

Palazzo, G. (2002), Die Mitte der Demokratie. Über die Theorie deliberativer Demokratie von Jürgen Habermas. (Baden-Baden: Nomos Verlagsgesellschaft)

Palazzo, G. (2005). Postnational constellations of innovativeness: A cosmopolitan approach. Technology Analysis and Strategic Management, 17(1), 55-72

Pels, D. (2003). Unhastening Science. Temporal demarcations in the 'Social Triangle'. European Journal of Social Theory, 6(2), 209-231

Peter, F. (2004). Choice, consent, and the legitimacy of market transactions. Economics and Philosophy, 20(1), 1-18

Pfeffer, J. (2005). Why do bad management theories persist? A comment on Ghoshal. Academy of Management Learning \& Education, 4(1), 96-100

Pfeffer, J. \& Fong, C. T. (2002). The end of business schools? Less success than meets the eye. Academy of Management Learning \& Education, 1(1), 78-95

Pfeffer, J. \& Fong, C. T. (2004). The business school 'business': Some lessons from the US experience. Journal of Management Studies, 41(8), 1501-1520

Plummer, J. T. (1984). How Personality Makes a Difference. Journal of Advertising Research, 24(6), $27-31$

Polanyi, K. (1957 [1944]), The Great Transformation. (Boston, MA: Beacon Press)

Popper, K. R. (1973), La logique de la découverte scientifique. (Paris: Payot)

Popper, K. R. (1978), La connaissance objective. (Bruxelles: Editions Complexe) 
Popper, K. R. (1993 [1989]). Liberté et responsabilité intellectuelle. Discours prononcé à l'Université de St.-Gall (In K. R. Popper (Ed.), La leçon de ce siècle. Entretien avec Giancarlo Bosetti, suivi de deux essais de Karl Popper sur la liberté et l'État démocratique (pp. 127-146). Paris: Anatolia Editions)

Popper, K. R. (2003 [1943]), The Open Society and Its Enemies. Volume 1: The Spell of Plato. (London: Routledge)

Popper, K. R. (2003 [1945]), The Open Society and its Enemies: Volume 2: Hegel and Marx. (London: Routledge)

Porter, M. E. \& Kramer, M. R. (2002). The competitive advantage of corporate philanthropy. Harvard Business Review, 80(12), 57-68

Pruzan, P. (2001). The question of organizational consciousness: Can organizations have values, virtues and visions? Journal of Business Ethics, 29(3), 271-284

Rainelli-Le Montagner, H. (2006). Financial theory on ethics: the reasons for silence. Finance \& the Common Good / Bien Commun(24), 20-27

Ratner, R. K. \& Miller, D. T. (2001). The norm of self-interest and its effects on social action. Journal of Personality and Social Psychology, 81(1), 5-16

Rees, R. (1985a). The theory of principal and agent: Part 1. Bulletin of Economic Research, 37(1), 3-26

Rees, R. (1985b). The theory of principal and agent: Part 2. Bulletin of Economic Research, 37(2), 7595

Reich, R. B. (1998). The new meaning of corporate social responsibility. California Management Review, 40(2), 8-17

Reiter, K. A. (2000). Harvard class of 2000 urged to pledge social responsibility. Harvard Crimson(March 20), retrieved 2007-04-25 from http://www.sriendowment.org/files/03-20-2000harvard.pdf

Rocha, H. O. \& Ghoshal, S. (2006). Beyond self-interest revisited. Journal of Management Studies, 43(3), 585-619

Rondinelli, D. A. (2002). Transnational corporations: international citizens or new sovereigns. Business and Society Review, 107(4), 391-413

Rosemann, N. (2005). The privatization of human rights violations - business' impunity or corporate responsibility? The case of human rights abuses and torture in Iraq. Non-State Actors and International Law, 5(1), 77-100

Rosenthal, S. B. \& Buchholz, R. A. (2000). The empirical-normative split in business ethics: A pragmatic alternative. Business Ethics Quarterly, 10(2), 399-408 
Rothberg, D. (2000). Spiritual Inquiry (In T. Hart, P. L. Nelson \& K. Puhakka (Eds.), Transpersonal Knowing: Exploring the horizon of Consciousness (pp. 161-184). Albany: State University of New York Press)

Rousseau, D. M. \& Tijoriwala, S. A. (1998). Assessing psychological contracts: issues, alternatives and measures. Journal of Organizational Behavior, 19, 679-695

Scherer, A. G. \& Palazzo, G. (2007). Toward a political conception of corporate responsibility. Business and society seen from a Habermasian perspective. Academy of Management Review(forthcoming)

Scherer, A. G., Palazzo, G. \& Baumann, D. (2006). Global rules and private actors - towards a new role of the TNC in the global governance. Business Ethics Quarterly, 16(4), 505-532

Schwartz, B. (1993). On the creation and destruction of value (In M. Hechter, L. Nadel \& R. E. Michod (Eds.), The Origin of Values (pp. 153-186). New York: Aldine De Gruyter)

Sen, A. (1977). Rational fools: A critique of the behavioral foundations of economic theory. Philosophy and Public Affairs, 6(4), 317-344

Sen, A. (1993). Capability and well-being (In M. C. Nussbaum \& A. Sen (Eds.), The Quality of Life (pp. 30-53). Oxford: Clarendon Press)

Sen, A. (1999), Development as Freedom. (Oxford: Oxford University Press)

Sen, S., Gürhan-Canli, Z. \& Morwitz, V. (2001). Withholding consumption: A social dilemma perspective on consumer boycotts. Journal of Consumer Research, 28, 399-417

Seth, A. \& Zinkhan, G. (1991). Strategy and the research process: A comment. Strategic Management Journal, 12(1), 75-82

Shamir, B., House, R. J. \& Arthur, M. B. (1993). The Motivational Effects of Charismatic Leadership: A Self-Concept Based Theory. Organization Science, 4(4), 577-594

Sharp Paine, L. (1994). Managing for organizational integrity. Harvard Business Review, 72(2), 106117

Sharp Paine, L. (1996). Moral thinking in management. An essential capability. Business Ethics Quarterly, 6(4), 477-492

Sims, R. R. \& Brinkmann, J. (2003). Enron ethics (or: Culture matters more than codes). Journal of Business Ethics, 45, 243-256

Smith, A. (1981 [1776]), An Inquiry into the Nature and Causes of the Wealth of Nations, Volume 1. (Indianapolis: Liberty Fund)

Smith, A. (1984 [1759]), The Theory of Moral Sentiments. (Indianapolis: Liberty Fund) 
Spain, J. W., Engle, A. D. \& Thompson, J. C. (2005). Applying multiple pedagogical methodologies in an ethics awareness week: Expectations, events, evaluation, and enhancements. Journal of Business Ethics, 58(1), 7-16

Steenhaut, S. \& van Kenhove, P. (2006). An empirical investigation of the relationships among a consumer's personal values, ethical ideology and ethical values. Journal of Business Ethics, 64(2), $137-155$

Stengers, I. (1993), L'invention des sciences modernes. (Paris: La Découverte)

Stigler, G. J. (1950a). The development of utility theory I. The Journal of Political Economy, 58, 307327

Stigler, G. J. (1950b). The development of utility theory II. The Journal of Political Economy, 58, 373396

Stiglitz, J. E. (2002), Globalization and Its Discontents. (New York \& London: W. W. Norton \& Company)

Stiglitz, J. E. (2003), The Roaring Nineties. Seeds of Destruction. (London et al.: Allen Lane)

Stryker, S. \& Vryan, K. D. (2003). The symbolic interactionist frame (In J. Delamater (Ed.), Handbook of Social Psychology (pp. 3-28). New York, Boston, Dordrecht, London, Moscow: Kluwer Academic / Plenum Publishers)

Swanson, D. L. (1999). Toward an Integrative Theory of Business and Society: A Research Strategy for Corporate Social Performance. Academy of Management Review, 24(3), 508-521

The Economist (2006). The heat is on. A special report on climate change. The Economist, 380(8494), S1-S24

Thompson, J. A. \& Bunderson, J. S. (2003). Violations of principle: ideological currency in the psychological contract. Academy of Management Review, 28(4), 571-586

Touraine, A. (1994), Qu'est-ce que la démocratie? (Paris: Fayard)

Trevino, L. K. \& Weaver, G. R. (1994). Business ETHICS/BUSINESS ethics: ONE FIELD OR TWO? Business Ethics Quarterly, 4(2), 113-128

Tversky, A. \& Kahneman, D. (1981). The framing of decisions and the psychology of choice. Science, $211,453-458$

Tversky, A. \& Kahneman, D. (1986). Rational choice and the framing of decisions. Journal of Business, 59(4 - Supplement), S251-S278

Ulrich, P. (1986), Transformation der ökonomischen Vernunft. Fortschrittsperspektiven der modernen Industriegesellschaft. (Bern, Stuttgart, \& Wien: Haupt) 
Ulrich, P. (2001), Integrative Wirtschaftsethik. Grundlagen einer lebensdienlicher Ökonomie. 3., revidierte Auflage edition. (Bern, Stuttgart, \& Wien: Haupt)

Ulrich, P. (2006). Politische Ökonomie, wirtschaftsethisch rekonfiguriert. Funktionale Systemökonomie im Kontext praktischer Sozialökonomie. Zeitschrift für Wirtschafts- und Unternehmensethik, 7(2), 164-182

Unerman, J. \& O'Dwyer, B. (2004). Enron, WorldCom, Andersen et al.: A challenge to modernity. Critical Perspectives on Accounting, 15(6-7), 971-993

Valor, C. (2005). Corporate social responsibility and corporate citizenship: Towards corporate accountability. Business and Society Review, 110(2), 191-212

Van Parijs, P. (1995), Real Freedom for All. What (if Anything) Can Justify Capitalism? (Oxford: Clarendon Press)

Vranceanu, R. (2005). The ethical dimension of economic choices. Business Ethics: A European Review, 14(2), 94-107

Wall, P. (2003). Marx was Right, LeadershipMatters (October 2003) retrieved on 2007-05-12 from http://www.bsignificant.com/2003/10.shtml

Walsh, J., Weber, K. \& Margolis, J. D. (2003). Social issues and management: Our lost cause found. Journal of Management, 29(6), 859-881

Weber, J. (2006). Implementing an organizational ethics program in an academic environment: the challenges and opportunities for the Duquesne University schools of business. Journal of Business Ethics, 65(1), 23-42

Weber, M. (1959 [1917]). La vocation de savant (In M. Weber (Ed.), Le savant et le politique (pp. 59107). Paris: Plon)

Weber, M. (1965 [1917]). Essai sur le sens de la «neutralité axiologique » dans les sciences sociologiques et économiques (In M. Weber (Ed.), Essais sur la théorie de la science (pp. 365433). Paris: Plon)

Weber, M. (1992 [1904]). L'objectivité de la connaissance dans les sciences et la politique sociales (In M. Weber (Ed.), essais sur la théorie de la science (pp. 117-201). Paris: Plon)

Weiss, T. (2006). New lessons in corporate citizenship, Forbes, retrieved 2006-11-29 from http://www.forbes.com/corporatecitizenship/2006/11/28/leadership-philanthropy-csr-lead-citizencx_tw_1128mba.html

Werhane, P. H. (1994). The normative/descriptive distinction in methodologies of business ethics. Business Ethics Quarterly, 4(2), 175-180 
Whetstone, J. T. (2005). A framework for organizational virtue: the interrelationship of mission, culture and leadership. Business Ethics: A European Review, 14(4), 367-378

Williams, R. J., Barrett, J. D. \& Brabston, M. (2000). Managers' business school education and military service: Possible links to corporate criminal activitiy. Human Relations, 53(5), 691-712

Williamson, O. E. (1975), Markets and Hierarchies: Analysis and Antitrust Organization. (New York: The Free Press)

Wood, D. J. \& Logsdon, J. M. (2001). Theorising business citizenship (In J. Andriof \& M. McIntosh (Eds.), Perspectives of Corporate Citizenship (pp. 83-103). Sheffield: Greenleaf Publishing)

Woolf, P. K. (1991). Accountability and responsibility in research. Journal of Business Ethics, 10(8), 595-600

Young, I. M. (2004). Responsibility and global labor justice. The Journal of Political Philosophy, 12, 365-388

Yuengert, A. (2002). Why did the economist cross the road? The hierarchical logic of ethical and economic reasoning. Economics and Philosophy, 18(2), 329-349

Zyglidopoulos, S. C. (2002). The social and environmental responsibilities of multinationals: Evidence from the Brent Spar Case. Journal of Business Ethics, 36, 141-151 